\title{
PENINGKATAN MOTIVASI DAN HASIL BELAJAR LEMPAR CAKRAM MELALUI MODIFIKASI CAKRAM DARI PIRING PLASTIK PADA SISWA SMP
}

\author{
Subroto \\ SMPN 4 Tegalombo Satap \\ brotosport@yahoo.co.id
}

\begin{abstract}
Abstrak
Modifikasi sarana dan prasana olahraga dapat dilakukan guru untuk pembelajaran Pendidikan Jasmani Olahraga dan Kesehatan (PJOK), salah satunya adalah modifikasi cakram dari piring plastikuntuk pembelajaran PJOK atletik nomor lempar cakram. Pembelajaran dapat dioptimalkandengan pemilihan alat pelajaran yang digunakan. Kesesuaian dan pemenuhan jumlah alat olahraga yang standar menjadikan pembelajaran dapat berjalan baik (optimal) karena semua siswa dapat terlibat dalam pembelajaran. Penelitian ini bertujuan untuk: (1) meningkatkan motivasi belajar lempar cakram pada siswa dan (2) meningkatkan hasil belajar lempar cakram pada siswa kelas IX A SMPN 4 Tegalombo Satap. Penelitian dilaksanakan dengan menggunakan rancangan penelitian tindakan kelas (classroomaction research). Tindakan yang diberikan dalam penelitian ini adalah penggunaan modifikasi cakram dari piring plastik untuk semua siswa dengan frekuensi yang cukup ketika pembelajaran. Hasil dari penelitian ini adalah: (1) terjadi peningkatan motivasi belajar siswa sebesar $7,8 \%$ setelah diberi tindakan pada siklus I dan 10,3\% pada siklus II, (2) terjadi peningkatan hasil belajar siswa sebesar 3,0 setelah diberi tindakan pada siklus I dan 4,5 pada siklus II. Peningkatan motivasi dan hasil belajar tersebut dapat disimpulkan bahwa hasil dari penelitian ini adalah: (1) modifikasi cakram dari piring plastik dapat meningkatkan motivasi belajar lempar cakram siswa dan (2) modifikasi cakram dari piring plastik dapat meningkatkan hasil belajar lempar cakram siswa.
\end{abstract}

Kata Kunci: motivasi belajar, hasil belajar, modifikasi cakram

\section{PENDAHULUAN}

Guru merupakan figur sentral pembelajaran sebagai penopang tercapai tujuan pembelajaran dan tujuan satuan pendidikan. Undang-undang No. 14 Tahun 2005 (2008:65) mengatur bahwa guru harus memiliki kompetensi pedagogik, kompetensi kepribadian, kompetensi sosial, dan kompetensi profesional yang diperoleh melalui pendidikan. Implementasi dari kompetensi pedagogik bahwa seorang guru harus merencanakan pembelajaran, melaksanakan proses pembelajaran yang bermutu, serta menilai dan mengevaluasi hasil pembelajaran.Susanto (2020:2) menyampaikan bahwa perencanaan berisi rangkaian putusan yang luas dan penjelasan-penjelasan tentang tujuan, penentuan kebijakan, penentuan program, penentuan metode-metode dan prosedur tertentu dan penentuan kegiatan berdasarkan jadwal seharihari. Rencana pembelajaran yang dituangkan guru dalam Rencana Pelaksanaan Pembelajaran
(RPP) salah satu diantaranya adalah pemilihan alat pembelajaran yang tepat untuk menunjang proses pelaksanaan pembelajaran bermutu sehingga tujuan pembelajaran dapat optimal.

Kurikulum yang dipakai di sekolah adalah Kurikulum 2013 yang dikembangkan atas dasar teori "pendidikan berdasarkan standar" (standardbased education), dan teori kurikulum berbasis kompetensi (Kemdikbud, 2013:84). Pendidikan Jasmani Olahraga dan Kesehatan (PJOK) merupakan salah satu mata pelajaran yang wajib diajarkan di sekolah dan merupakan bagian dari pendidikan secara keseluruhan yang bertujuan untuk mengembangkan aspek kebugaran jasmani, keterampilan gerak, keterampilan berfikir kritis, keterampilan sosial, penalaran, stabilitas emosional, tindakan moral, aspek pola hidup sehat, pengenalan lingkungan bersihmelaluiaktivitasjasmani, olahraga dan kesehatan terpilih yang direncanakan secara sistematis dalam rangka mencapai tujuan pendidikan 
nasional (BSNP, 2006: 512). Implementasi PJOK di sekolah memang mempunyai keunikan yang spesifik dibandingkan dengan mata pelajaran lain diantaranya adalah aktivitas fisik yang dilakukan siswa dan penggunakan alat-alat olahraga sesuai jenis olahraga dan permainan yang diajarkan.

Kompetensi guru dalam merencanakan dan melaksanakan pembelajaran yang tepat akan berpengaruh pada hasil belajar siswa sebagai indikasi tercapainya tujuan pembelajaran. Hasil belajar menjadi indikator sejauh mana proses pembelajaran dapat merubah kemampuan siswa yang tidak sama antara satu dengan yang lain. Para pakar pendidikan berpendapat bahwa kemampuan dari hasil belajar mencakup 3 ranah yaitu kognitif (pengetahuan), afektif (sikap), dan psikomotor (keterampilan). Hasil belajar adalah perubahan perilaku secara keseluruhan bukan hanya salah satu aspek potensi kemanusiaan saja. Artinya, hasil pembelajaran yang dikategorisasi oleh para pakar pendidikan sebagaimana tersebut di atas tidak dilihat secara fragmentaris atau terpisah, melainkan komprehensif. Maisaroh dan Rostrieningsih (2010:2) dalam penelitiannya menyimpulkan bahwa hasil belajar adalah hasil yang diperoleh seseorang dalam proses kegiatan belajar mengajar dan hasil tersebut dapat berbentuk kognitif, afektif, dan psikomotorik yang penilaiannya melalui tes. Sudijono (2014:32) memberikan uraian yang sama bahwa hasil belajar merupakan sebuah tindakan evaluasi yang mengungkap aspek proses berpikir (cognitive domain) juga dapat mengungkap aspek kejiwaan lainnya, yaitu aspek nilai dan sikap (affective domain) dan aspek keterampilan (psichomotor domain) yang melekat pada diri setiap individu peserta didik.

Hasil belajar dipengaruhi oleh banyak faktor, di antaranya seperti yang disampaikan Slameto (2010:54) yaitu motivasi (faktor psikologis) sebagai faktor internal dan alat pelajaran (faktor sekolah) sebagai faktor eksternal. Motivasi dan hasil belajar merupakan dua permasalahan yang sering dibahas oleh banyak pakar pendidikan karena berpengaruh pada pencapaian tujuan pembelajaran dan pendidikan. Komarudin (2013:24) bahwa motivasi dapat didefinisikan sebagai dorongan yang berasal dari dalam maupun dari luar diri individu untuk melakukan suatu aktivitas yang bisa menjamin kelangsungan aktivitas tersebut, serta dapat menentukan arah dan besaran upaya yang dikerahkan untuk melakukan aktivitas sehingga dapat mencapai tujuan yang telah ditetapkan. Muhammad (2016:94) mengutip pendapat Lindargen bahwa faktor internal berupa kebutuhan, keinginan, emosi dan ketertarikan. Dan faktor eksternal berupa keadaan yang menjamin individu sikap dan harapan dari orang lain terhadap dirinya, ganjaran dan ancaman. Kedua motivasi tersebut mempunyai peran penting dalam menggerakkan seseorang mengerahkan kemampuannya untuk mencapai suatu tujuan yang diinginkan.

Guru sebagai sosok penting dalam memberikan motivasi pada siswa untuk terlibat aktif dan energik dalam pembelajaran yang dikelolanya. Thohari (2013:56) dalam bukunya menyatakan bahwa pembelajaran yang dikelolanya menjadi penuh motivasi dan bermakna besar bagi pengembangan diri putra-putrinya di ruang kelas yang energik. Rancangan pembelajaran yang disusun dengan baik tidak dapat berjalan optimal jika guru gagal membangkitkan motivasi siswa terlibat aktif di dalamnya. Siswa akan termotivasi jika: (a) yakin bahwa apa yang dipelajari bermanfaat bagi dirinya, (b) yakin akan mampu memahami/menguasai pelajaran tersebut, (c) situasi belajar menyenangkan (Depdiknas, 2000:145). Tiga faktor penyebab motivasi pada siswa tersebut harus menjadi acuan bagi guru dalam mengelola pembelajaran.

Faktor lain agar pembelajaran dapat optimal adalah pemilihan alat pelajaran yang digunakan. Kesesuaian dan pemenuhan jumlah alat olahraga yang standar menjadikan pembelajaran dapat berjalan baik (optimal) karena semua siswa dapat terlibat dalam pembelajaran. Pratomo (2013:373) menyatakan bahwa kelancaran pembelajaran PJOK dapat diukur salah satunya dari ketersediaan sarana dan prasana. Sarana dan prasarana yang memadai akan mencerminkan kualitas pembelajaran yang dilakukan, sehingga tujuan pembelajaran akan tercapai dengan baik. Dominasi siswa tertentu ketika 
praktek penguasaan gerakan/teknik dasar olaraga dan permainan dapat dihindari, sehingga semua siswa lebih semangat atau bertambah motivasinya pada saat kegiatan pembelajaran.

Realita yang terjadi ternyata masih ada kesenjangan antara harapan dan kenyataan.Kondisi tersebut bisa ditemui: (1) di SMPN 4 Tegalombo Satap kegiatan pembelajaran PJOK tidak didukung oleh alat yang memadai, baik standar kualitas maupun kuantitasnya. Artinya selain mutu alat yang belum memenuhi standar, kuantitasnya tidak sebanding dengan jumlah siswa, (2) sekalipun ada peralatan yang standar ternyata belum tentu bisa menjamin cocok dan sesuai dengan karakteristik siswa. Permasalahan sering terjadi pada saat kegiatan pembelajaran berlangsung banyak siswa yang tidak bisa menjadi pemain utama untuk berperan aktif sesuai dengan harapan. Siswa hanya sekedar sebagai penonton melihat teman-temannya beraktivitas. Siswa kurang semangat dalam mengikuti kegiatan pembelajaran karena peralatan yang digunakan dianggap memberatkan dalam beraktivitas sehingga kurang menarik minat siswa.

Rendahnya semangat siswa akan berdampak buruk terhadap totalitas kegiatan pembelajaran. Guru tentu saja telah kehilangan separuh dari kesempatan untuk mampu memberikan layanan yang terbaik bagi siswanya.Kemudian muncul berbagai persoalan seperti; guru kesulitan dalam mengelola kegiatan kelas, banyak waktu terbuang, kegiatan siswa tidak optimal, akibatnya berdampak pada tidak optimalnya aktivitas belajaryang berujung pada tidak tercapainya tujuan pembelajaran.

Situasi dan kondisi kegiatan pembelajaran seperti dipaparkan di atas juga peneliti alami saat kegiatan pembelajaran PJOK pada materi nomor lempar cakram. Saat kegiatan pembelajaran lempar cakram di kelas IX A SMPN 4 Tegalombo Satap berlangsung terdapat gejala-gejala perilaku yangkurang baik pada siswa seperti; kurang antusias, tidak sungguh-sungguh, tidak menunjukkan kegembiraan, aktivitas fisik tidak optimal, sehingga perolehan keterampilan gerak baru pada siswa berlangsung lambat. Hasil evaluasi menunjukkan bahwa ketuntasan hasil belajar secara klasikal dari
20 siswa yang tercapai adalah $65 \%$ atau 13 siswa dinyatakan tuntas, sedangkan $35 \%$ atau 7 siswa belum tuntas (belum memenuhi KKM).

Identifikasi masalah dari kegiatan pembelajaran lempar cakram menunjukkan bahwa siswa mengalami kesulitan saat mempelajari gerak lempar cakram. Hal ini disebabkan; (1) tingkat kesulitan gerakan lempar cakram memang cukup komplek, (2) belajar dengan peralatan cakram yang sesungguhnya dirasa menyulitkan karena alat yang berat dan dianggap kurang menarik khususnya bagi siswa yang baru belajar, (3) kesempatan siswa menggunakan cakram sangat kurang karena jumlah cakram yang digunakan hanya 2 buah.

Berdasarkan uraian permasalahan maka diterapkan konsep sederhana yaitu memanfaatkan barang yang mudah dicari dengan spesifikasi bahan yang ringan melalui modifikasi cakram dari piring plastik, sebagai alternatif pengganti cakram untuk memudahkan siswa belajar teknik dasar lempar cakram. Harapan dari layanan pembelajaran ini adalah meningkatnya motivasi dan hasil belajar lempar cakram pada siswa dengan alasan (1) adanya penelitian sebelumnya yaitu Penerapan Modifikasi Alat Pembelajaran Pendidikan Jasmani untuk Peningkatan Hasil Belajar Atletik Nomor Lempar Cakram pada Siswa Kelas VIII SMP Muhammadiyah 1 Pringsewu oleh Angga Priakusuma dkk., (2) pengelolaan kelas lebih mudah karena keterlibatan semua siswa dalam pembelajaran. Maka dilakukan langkah-langkah ilmiah melalui penelitian tindakan kelas dengan judul: "Upaya Meningkatkan Motivasi dan Hasil Belajar Lempar Cakram Melalui Modifikasi Cakram dari Piring Plastik pada Siswa Kelas IX A SMPN 4 Tegalombo Satap ".

Berdasarkan judul penelitian maka rumusan masalah penelitian ini adalah; (1) apakah modifikasi cakram dari piring plastik dapat meningkatkan motivasi belajar lempar cakram? dan (2) apakah modifikasi cakram dari piring plastik dapat meningkatkan hasil belajar lempar cakram? Tujuan penelitian ini untuk mengetahui; (1) peningkatan motivasi siswa belajar lempar cakram melalui modifikasi cakram dari piring plastik dan (2) 
peningkatan hasil belajar lempar cakram melalui modifikasi cakram dari piring plastik.

\section{METODE}

Penelitian ini merupakan penelitian tindakan kelas (classroom action research) yang dilakukan pada pembelajaran PJOK kompetensi dasar lempar cakram gaya menyamping. Menurut Arikunto (2012:3) Clasroom Action Research merupakan sebuah kegiatan penelitian yang dilakukan di dalam kelas. Tindakan yang dilakukan adalah pemakaian modifikasi cakram dari plastik (1 cakram untuk 2 siswa), sehingga semua siswa mendapat kesempatan yang sama untuk praktek penguasaan teknik dasar lempar cakram. Penilitian dilaksanakan pada semester genap Tahun Pelajaran 2018/2019 mulai tanggal 14 Januari 2019 s.d. 25 Maret 2019. Subyek penelitian adalah siswa kelas IX A SMPN 4 Tegalombo Satap dengan jumlah 20 anak terdiri dari 12 anak putri dan 8 anak putra.

Prosedur dalam penelitian ini adalah: (1) mengidentifikasi masalah yang dilakukan berdasarkan hasil observasi dan angket siswa terhadap proses pembelajaran yang dilakukan, (2) merumuskan masalah yang dilakukan secara kolaborasi antara peneliti sebagai guru (pembelajar yang diobservasi) dengan guru pengamat, (3) menyusun rencana tindakan (siklus I) secara kolaborasi, (4) melakukan tindakan (proses pembelajaran) sesuai rencana, dan observasi terhadap pelaksanaan pembelajaran (action) yang sedang dilakukan oleh guru PJOK dan angket yang diisi oleh siswa, (5) merefleksi tindakan (pelaksanaan pembelajaran) yang dilakukan oleh guru, (6) berdasarkan hasil observasi, angket, dan refleksi apabila ada kelemahan/kekurangan yang terjadi pada saat tindakan dilakukan revisi rencana, dan (7) secara kolaborasi antarapeneliti dan pengamat menyusun revisi rencana selanjutnya hingga hasil analisis observasi, angket, dan refleksi tidak menampakkan adanya kelemahan/kekurangan maka kegiatan penelitian dianggap selesai. Prosedur yang sama dilakukan untuk siklus II sesuai dengan rancangan PTK ini yaitu dengan 2 siklus. Alur dari siklus penelitian tindakan kelas seperti pada gambar 1.

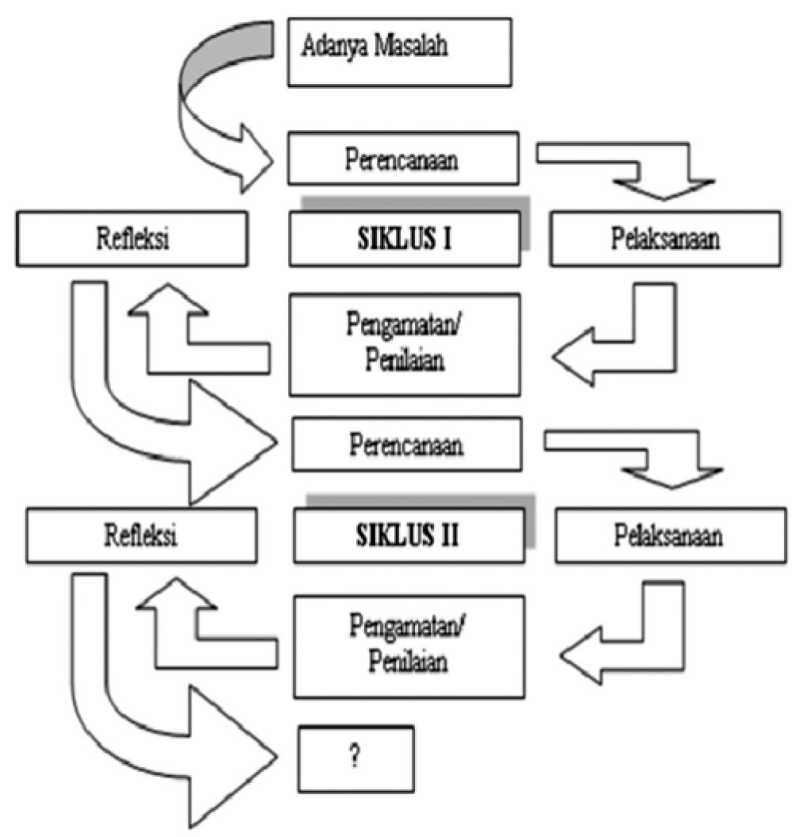

Gambar 1. Siklus PTK

(Sumber Arikunto, 2012:27)

Instrumen dalampenelitian ini adalah lembar angket untuk mendapatkan data tentang kepuasan siswa terhadap proses pembelajaran dan lembar observasi penilaian hasil belajar siswa ranah afektif, kognitif, dan psikomotor. Teknik pengumpulan data yaitu; (a) pemberian angket pada siswa setelah pembelajaran pada tiap siklus untuk mengetahui motivasi siswa terhadap proses pembelajaran, (b) observasi lapangan secara langsung oleh kolaborator dengan mengisi lembar observasi keterlaksanaan pengelolaan pembelajaran, dan (c) pengamatan peneliti dengan format observasi penilaian hasil belajar siswa untuk mengetahui hasil belajar lempar cakram. Teknik pengumpulan data seperti termuat pada tabel 1 . 
Tabel 1. Teknik Pengumpulan Data PTK Pembelajaran Lempar Cakram

\begin{tabular}{cclll}
\hline No & $\begin{array}{c}\text { Sumber } \\
\text { Data }\end{array}$ & \multicolumn{1}{c}{ Jenis Data } & \multicolumn{1}{c}{$\begin{array}{c}\text { Teknik } \\
\text { Pengumpulan Data }\end{array}$} & Instrumen \\
\hline 1. & Siswa & $\begin{array}{l}\text { Respon siswa(tingkat motivasi } \\
\text { belajar) terhadap proses belajar }\end{array}$ & $\begin{array}{l}\text { Penyebaran angket Angket kepuasan } \\
\text { belajar siswa (diisi siswa) }\end{array}$ & Angket \\
\hline 2. & Guru & Keterlaksanaan pembelajaran & Observasi (kolaborator) & $\begin{array}{l}\text { Pedoman } \\
\text { Observasi }\end{array}$ \\
\hline 3. & Siswa & Hasil Belajar siswa & $\begin{array}{l}\text { Tes unjuk kerja siswa ranah afektif, } \\
\text { kognitif, psikomotor }\end{array}$ & $\begin{array}{l}\text { Lembar } \\
\text { penilaian }\end{array}$ \\
\hline
\end{tabular}

Indikator untuk meningkatkan motivasi siswa diukur dengan instrumen layanan pembelajaran (angket) dengan 4 pilihan jawaban (sangat setuju skor 4, setuju skor 3, tidak setuju skor 2, sangat tidak setuju skor 1). Indikator hasil belajar diukur dengan menggunakan instrumen layanan pembelajaran serta instrumen penilaian lempar cakram. Adapun rincian instrumennya adalah sebagai berikut; (1) angket motivasi belajar siswa dan (2) angket keterlaksanaan pengelolaan pembelajaran (instrumen penilaian lemparcakram): lembar observasi sikap, soal tertulis/ rubrik penilaian pengetahuan, tes keterampilan/ rubrik penilaian keterampilan. Kriteria ketuntasan minimal ditentukan pada angka 75 (KTSP 2006) dengan kategori; amat baik: 91 - 100, baik: 75 - 90, cukup: $60-74$, kurang: $40-59$ dan kurang sekali: $<40$.

Peningkatan hasil belajar lempar cakram dibuktikan dengan membandingkan proses dan hasil pembelajaran antara siklus I dengan siklus II.Hasil belajar lempar cakram tersebut seperti kriteria Depdikbud (2013:331) diperoleh melalui penggabungan nilai tes unjuk kerja (keterampilan), nilai observasi (sikap), dan nilai kuis (keterampilan).

\section{HASIL DAN PEMBAHASAN}

Data awal dari pembelajaran lempar cakram siswa kelas IX A SMPN 4 Tegalombo Satap pada hari Senin, 7 Januari 2019 ditemukan data motivasi belajar siswa 74,1\%. Hasil belajar siswa 74,8 (ranah afektif 76,1, kognitif 74,5, psikomotor 74,3). Ketuntasan belajar adalah 13 siswa sudah memenuhi ketuntasan belajar dan 7 siswa belum tuntas.
Data tersebut menjadi indikator bahwa motivasi dan hasil belajar masih rendah. Pembelajaran kurang efektif karena salah satu faktornya alat pembelajaran kurang memenuhi kebutuhan gerak siswa (hanya ada 2 buah cakram untuk 20 siswa). Siswa kurang mendapat kesempatan yang cukup untuk mempraktekkan teknik dasar lempar cakram sehingga motivasi belajar rendah. Langkah yang dilakukan guru untuk meningkatkan motivasi dan hasil belajar siswa adalah penelitian tindakan yang dilaksanakan sebanyak 2 siklus.

\section{Deskripsi tindakan dan hasil pada siklus I}

Deskripsi tindakan siklus I meliputi tahap; 1) kegiatan persiapan tindakan, yaitu (a) menyiapkan peralatan berupa cakram dari piring plastik sejumlah 10 buah, lapangan, petugas yang membantu, dan instrumen pengumpulan data penelitian, (b) mengarahkan siswa tentang kegiatan pembelajaran menggunakan cakram dari piring plastik. Tahap 2) kegiatan tindakan, yaitu pelaksanaan pembelajaran lempar cakram dengan menggunakan modifikasi cakram dari piring plastik. Tahapan tindakan adalah; (a) pertemuan 1 (Senin, 21 Januari 2019) siswa dibimbing guru berlatih teknik dasar lempar cakram menggunakan modifikasi cakram dari piring plastik, kemudian dengan cakram yang sebenarnya. (b) pertemuan 2 (Senin, 28 Januari 2019) siswa mengulangi lagi latihan teknik dasar lempar cakram dengan modifikasi cakram dari piring plastik, dilanjutkan dengan cakram yang sebenarnya. Pada pertemuan ke-2 dilakukan penilaian lempar cakram dan instrumen motivasi untuk diisi siswa.

Berdasarkan instrumen yang diisi oleh siswa setelah pembelajaran dapat disajikan pada tabel berikut; 
Tabel 2. Analisis Angket Motivasi Belajar Siswa Terhadap ProsesPembelajaran Lempar Cakram Siklus I

\begin{tabular}{|c|c|c|c|c|c|c|c|c|c|}
\hline \multirow{2}{*}{$\begin{array}{c}\text { NO } \\
\text { SOAL }\end{array}$} & \multicolumn{5}{|c|}{$\Sigma$ JAWABAN SISWA } & \multicolumn{4}{|c|}{$\%$ PILIHAN JAWABAN } \\
\hline & SS & $\mathrm{S}$ & TS & STS & $\mathrm{JML}$ & SS & $\mathrm{S}$ & TS & STS \\
\hline 1 & 9 & 8 & 2 & 1 & 20 & 45.0 & 40.0 & 10.0 & 5.0 \\
\hline 2 & 9 & 8 & 2 & 1 & 20 & 45.0 & 40.0 & 10.0 & 5.0 \\
\hline 3 & 8 & 8 & 3 & 1 & 20 & 40.0 & 40.0 & 15.0 & 5.0 \\
\hline 4 & 9 & 8 & 2 & 1 & 20 & 45.0 & 40.0 & 10.0 & 5.0 \\
\hline 5 & 8 & 8 & 2 & 2 & 20 & 40.0 & 40.0 & 10.0 & 10.0 \\
\hline 6 & 9 & 7 & 2 & 2 & 20 & 45.0 & 35.0 & 10.0 & 10.0 \\
\hline 7 & 8 & 8 & 2 & 2 & 20 & 40.0 & 40.0 & 10.0 & 10.0 \\
\hline 8 & 9 & 8 & 2 & 1 & 20 & 45.0 & 40.0 & 10.0 & 5.0 \\
\hline 9 & 9 & 8 & 2 & 1 & 20 & 45.0 & 40.0 & 10.0 & 5.0 \\
\hline 10 & 8 & 8 & 2 & 2 & 20 & 40.0 & 40.0 & 10.0 & 10.0 \\
\hline 11 & 9 & 7 & 2 & 2 & 20 & 45.0 & 35.0 & 10.0 & 10.0 \\
\hline 12 & 9 & 8 & 2 & 1 & 20 & 45.0 & 40.0 & 10.0 & 5.0 \\
\hline 13 & 8 & 8 & 3 & 1 & 20 & 40.0 & 40.0 & 15.0 & 5.0 \\
\hline 14 & 9 & 8 & 2 & 1 & 20 & 45.0 & 40.0 & 10.0 & 5.0 \\
\hline 15 & 7 & 8 & 3 & 2 & 20 & 35.0 & 40.0 & 15.0 & 10.0 \\
\hline 16 & 9 & 8 & 2 & 1 & 20 & 45.0 & 40.0 & 10.0 & 5.0 \\
\hline 17 & 8 & 7 & 3 & 2 & 20 & 40.0 & 35.0 & 15.0 & 10.0 \\
\hline \multirow[t]{2}{*}{18} & 9 & 8 & 2 & 1 & 20 & 45.0 & 40.0 & 10.0 & 5.0 \\
\hline & 154 & 141 & 40 & 25 & 360 & 770.0 & 705.0 & 200.0 & 125.0 \\
\hline \multirow{2}{*}{\multicolumn{6}{|c|}{ Jumlah dalam \% }} & 42.78 & 39.17 & 11.11 & 6.94 \\
\hline & & & & & & \multicolumn{2}{|c|}{81.9} & \multicolumn{2}{|c|}{18.1} \\
\hline
\end{tabular}

Berdasarkan tabel 2 tingkat motivasi belajar siswa setelah tindakan I adalah $81,9 \%$, sehingga terjadi peningkatan $7,8 \%$ dari sebelum diberi tindakan yaitu $74,1 \%$. Data tersebut dikategorikan klasifikasi baik dan dapat ditingkatkan.
Deskripsi peningkatan hasil belajar setelah pembelajaran dengan menggunakan modifikasi cakram dari piring plastikdilakukan, seperti disajikan dalam tabel nilai sebagai berikut. 
Tabel 3. Nilai Hasil Belajar Lempar Cakram Siklus I

\begin{tabular}{|c|c|c|c|c|c}
\hline \multirow{2}{*}{ No } & \multirow{2}{*}{ NAMA SISWA } & \multicolumn{3}{c}{ NILAI } & \multirow{2}{*}{ N.AKHIR } \\
\cline { 3 - 5 } & & AFEKTIF & KOGNITIF & PSIKOMOTOR & \\
\hline \hline 1 & AFRIZAL & 78 & 72 & 73 & 74 \\
\hline 2 & AGUS RIAWAN & 79 & 76 & 76 & 77 \\
\hline 3 & ALFIN & 79 & 75 & 78 & 78 \\
\hline 4 & ANANDA DWI SAPUTRI & 77 & 73 & 73 & 74 \\
\hline 5 & ANISA SEPTYA NINGRUM & 76 & 72 & 74 & 74 \\
\hline 6 & ANNISA FITRI FIRNANDA & 82 & 79 & 80 & 80 \\
\hline 7 & DINA YUNIANTI & 79 & 76 & 81 & 79 \\
\hline 8 & FEBRI ARDIANSYAH & 81 & 77 & 79 & 79 \\
\hline 9 & FEMILIA AWANDA & 78 & 78 & 78 & 78 \\
\hline 10 & INDAH MEILIA & 79 & 71 & 73 & 74 \\
\hline 11 & LILIK WIRAWATI & 81 & 78 & 79 & 79 \\
\hline 12 & NOFITA SARI & 78 & 79 & 81 & 80 \\
\hline 13 & PIPIT SEPTIANA & 80 & 78 & 73 & 76 \\
\hline 14 & RIKA SETIANA & 80 & 78 & 76 & 78 \\
\hline 15 & RIYAN PRASETYO & 80 & 78 & 80 & 80 \\
\hline 16 & RIZKY VRILIANSYAH & 81 & 76 & 79 & 79 \\
\hline 17 & SAHRUL GUNAWAN & 81 & 76 & 78 & 79 \\
\hline 18 & SRI MULYANI & 81 & 80 & 78 & 79 \\
\hline 19 & SUNARTI & 81 & 79 & 78 & 79 \\
\hline 20 & WAHYU & 79 & 75 & 80 & 79 \\
\hline Nilai Rata-rata & $\mathbf{7 9 . 5}$ & $\mathbf{7 6 . 3}$ & $\mathbf{7 7 . 4}$ & $\mathbf{7 7 . 8}$ \\
\hline \hline Ketuntas an belajar: & & & & \\
\hline & \multirow{2}{*}{ NILAI AKHIR } & TUNTAS & BELUM TUNTAS \\
\cline { 2 - 5 } & Jml & $\%$ & Jml & $\%$ \\
\hline Hasil belajar lempar cakram & 16 & 80 & 4 & 20 \\
\hline & & & & & \\
\hline
\end{tabular}

Berdasarkan tabel hasil belajar siklus I diatas dapat dijelaskan sebagai berikut; 1) Nilai rata-rata aspek afektif adalah 79,5 (kategori baik bisa ditingkatkan), 2) Nilai rata-rata aspek kognitif adalah 76,3 (kategori baik bisa ditingkatkan), 3) Nilai rata-rata aspek psikomotor adalah 77,4 (kategori baik bisa ditingkatkan), 4) Rata-rata nilai akhir (gabungan dari aspek afektif, kognitif, dan psikomotor) adalah 77,8 (kategori baik bisa ditingkatkan), 5) Ketuntasan belajar adalah 16 siswa dinyatakan tuntas dan 4 siswa belum tuntas karena nilainya masih berada di bawah KKM yaitu 75 .

Peneliti dan kolaborator berdiskusi sebagai langkah refleksi diantaranya; 1) bentuk latihan siswa dengan cakram dari piring plastik terlalu monoton sehingga kurang menarik bagi siswa, 2) sebaiknya memanfaatkan tutor sebaya dalam memudahkan pembimbingan sehingga pembelajaran berlangsung efektif dan efisien, 3) ditayangkan video latihan lempar cakram untuk menambah gambaran siswa tentang belajar lempar cakram. Hasil dari refleksi juga digunakan untuk merancang siklus II guna memperbaiki kekurangan atau kelemahan yang terjadi pada siklus I.

\section{Deskripsi tindakan dan hasil pada siklus II}

Pelaksanaan siklus II mirip dengan pelaksanaan pada siklus I. Perubahan yang dilakukan berdasarkan evaluasi dan refleksi dari tindakan siklus I. Kegiatan dalam siklus II mengacu pada rencana perbaikan tindakan berdasarkan hasil refleksi pelaksanaan siklus I. Kegiatan yang dimaksud meliputi: 1) kegiatan persiapan tindakan, yaitu (a) menyiapkan peralatan berupa cakram 
dari piring plastik sejumlah 10 buah (1 cakram untuk 2 siswa), lapangan lempar cakram, dan LCD untuk menayangkan video pembelajaran lempar cakram, petugas yang membantu, dan instrumen pengumpulan data penelitian, (b) mengarahkan siswa tentang kegiatan pembelajaran lempar cakram menggunakan cakram dari piring plastik. Tahap 2) kegiatan tindakan, yaitu pelaksanaan pembelajaran lempar cakram dengan menggunakan modifikasi cakram dari piring plastik. Tahapan tindakan adalah; (a) pertemuan 1 (Senin, 11 Februari 2019) siswa dibimbing guru berlatih teknik dasar lempar cakram dengan menggunakan alat modifikasi cakram yang terbuat dari piring plastik. Setelah latihan teknik dasar cakram dengan cakram dari piring plastik dilanjutkan dengan menggunakan cakram yang sebenarnya (b) pertemuan 2 (Senin, 18 Febuari
2019) siswa dibimbing gurumengulangi lagi berlatih teknik dasar lempar cakram dengan menggunakan alat modifikasi cakram yang terbuat dari piring plastik. Setelah latihan teknik dasar cakram dengan cakram dari piring plastik dilanjutkan dengan menggunakan cakram yang sebenarnya. Guru membuat skenario pembelajaran yang lebih variatif agar siswa tidak jenuh selama belajar lempar cakram. Pada pertemuan kedua guru melakukan penilaian lempar cakram dan memberikan instrumen motivasi untuk diisi oleh siswa.

Berdasarkan rekam data hasil pengamatan selama proses pembelajaran pada siklus Ilyang didapat dari penggalian angket motivasi kepuasan siswa terhadap proses pembelajaran yang diisi oleh peserta didik disajikan pada tabel berikut:

Tabel 4. Analisis Angket Motivasi Belajar Siswa Terhadap Proses Pembelajaran Lempar Cakram Siklus II

\begin{tabular}{|c|c|c|c|c|c|c|c|c|c|}
\hline \multirow{2}{*}{$\begin{array}{c}\mathrm{NO} \\
\text { SOAL }\end{array}$} & \multicolumn{5}{|c|}{$\Sigma$ JAWABAN SISWA } & \multicolumn{4}{|c|}{$\%$ PILIHAN JA WABAN } \\
\hline & SS & $\mathrm{S}$ & $\mathrm{TS}$ & STS & JML & SS & $\mathrm{S}$ & $\mathrm{TS}$ & STS \\
\hline 1 & 10 & 8 & 1 & 1 & 20 & 50.0 & 40.0 & 5.0 & 5.0 \\
\hline 2 & 10 & 9 & 1 & 0 & 20 & 50.0 & 45.0 & 5.0 & 0.0 \\
\hline 3 & 9 & 10 & 1 & 0 & 20 & 45.0 & 50.0 & 5.0 & 0.0 \\
\hline 4 & 9 & 9 & 1 & 1 & 20 & 45.0 & 45.0 & 5.0 & 5.0 \\
\hline 5 & 9 & 10 & 1 & 0 & 20 & 45.0 & 50.0 & 5.0 & 0.0 \\
\hline 6 & 10 & 8 & 1 & 1 & 20 & 50.0 & 40.0 & 5.0 & 5.0 \\
\hline 7 & 10 & 9 & 1 & 0 & 20 & 50.0 & 45.0 & 5.0 & 0.0 \\
\hline 8 & 9 & 9 & 1 & 1 & 20 & 45.0 & 45.0 & 5.0 & 5.0 \\
\hline 9 & 10 & 8 & 1 & 1 & 20 & 50.0 & 40.0 & 5.0 & 5.0 \\
\hline 10 & 9 & 9 & 1 & 1 & 20 & 45.0 & 45.0 & 5.0 & 5.0 \\
\hline 11 & 10 & 8 & 1 & 1 & 20 & 50.0 & 40.0 & 5.0 & 5.0 \\
\hline 12 & 10 & 8 & 1 & 1 & 20 & 50.0 & 40.0 & 5.0 & 5.0 \\
\hline 13 & 10 & 9 & 1 & 0 & 20 & 50.0 & 45.0 & 5.0 & 0.0 \\
\hline 14 & 9 & 9 & 1 & 1 & 20 & 45.0 & 45.0 & 5.0 & 5.0 \\
\hline 15 & 11 & 8 & 1 & 0 & 20 & 55.0 & 40.0 & 5.0 & 0.0 \\
\hline 16 & 9 & 10 & 1 & 0 & 20 & 45.0 & 50.0 & 5.0 & 0.0 \\
\hline 17 & 11 & 8 & 1 & 0 & 20 & 55.0 & 40.0 & 5.0 & 0.0 \\
\hline \multirow[t]{2}{*}{18} & 9 & 9 & 1 & 1 & 20 & 45.0 & 45.0 & 5.0 & 5.0 \\
\hline & 174 & 158 & 18 & 10 & 360 & 870.0 & 790.0 & 90.0 & 50.0 \\
\hline \multirow{2}{*}{\multicolumn{6}{|c|}{ Jumlah dalam \% }} & 48.3 & 43.9 & 5.0 & 2.8 \\
\hline & & & & & & \multicolumn{2}{|c|}{92.2} & \multicolumn{2}{|c|}{7.8} \\
\hline
\end{tabular}


Berdasarkan tabel di atas tingkat motivasi belajar siswa setelah tindakan II adalah 92,2\% , sehingga terjadi peningkatan $10,3 \%$ dari tindakan I yaitu $81,9 \%$. Data tersebut dapat dikategorikan pada klasifikasi amat baik.
Deskripsi peningkatan hasil belajar setelah pembelajaran dengan menggunakan modifikasi cakram dari piring plastikdilakukan, seperti disajikan dalam tabel nilai sebagai berikut.

Tabel 5. Nilai Hasil Belajar Lempar Cakram Siklus II

\begin{tabular}{|c|c|c|c|c|c|}
\hline \multirow{2}{*}{ No } & \multirow{2}{*}{ NAMA SISWA } & \multicolumn{3}{|c|}{ NILAI } & \multirow{2}{*}{ N.AKHIR } \\
\hline & & AFEKTIF & KOGNITIF & PSIKOMOTOR & \\
\hline 1 & AFRIZAL & 80 & 80 & 82 & 81 \\
\hline 2 & AGUS RIAWAN & 81 & 84 & 83 & 83 \\
\hline 3 & ALFIN & 82 & 88 & 84 & 84 \\
\hline 4 & ANANDA DWI SAPUTRI & 80 & 81 & 82 & 81 \\
\hline 5 & ANISA SEPTYA NINGRUM & 81 & 86 & 82 & 83 \\
\hline 6 & ANNISA FITRI FIRNANDA & 82 & 87 & 84 & 84 \\
\hline 7 & DINA YUNIANTI & 81 & 83 & 83 & 82 \\
\hline 8 & FEBRI ARDIANSYAH & 81 & 85 & 84 & 83 \\
\hline 9 & FEMILIA AWANDA & 80 & 84 & 83 & 82 \\
\hline 10 & INDAH MEILIA & 80 & 82 & 84 & 82 \\
\hline 11 & LILIK WIRAWATI & 81 & 82 & 82 & 82 \\
\hline 12 & NOFITA SARI & 80 & 82 & 84 & 82 \\
\hline 13 & PIPIT SEPTIANA & 80 & 83 & 81 & 81 \\
\hline 14 & RIKA SETIANA & 80 & 80 & 81 & 81 \\
\hline 15 & RIYAN PRASETYO & 80 & 84 & 85 & 83 \\
\hline 16 & RIZKY VRILIANSYAH & 81 & 87 & 84 & 84 \\
\hline 17 & SAHRUL GUNAWAN & 81 & 87 & 83 & 83 \\
\hline 18 & SRI MULYANI & 81 & 80 & 80 & 80 \\
\hline 19 & SUNARTI & 81 & 82 & 81 & 81 \\
\hline 20 & WAHYU & 80 & 86 & 82 & 82 \\
\hline \multicolumn{2}{|c|}{ Nilai Rata-rata } & 80.7 & 83.7 & 82.7 & 82.3 \\
\hline \multicolumn{6}{|c|}{ Ketuntasan belajar: } \\
\hline & \multirow{2}{*}{ NILAI AKHIR } & \multicolumn{2}{|c|}{ TUNTAS } & \multicolumn{2}{|c|}{ BELUM TUNTAS } \\
\hline & & Jml & $\%$ & Jml & $\%$ \\
\hline & Hasil belajar lempar cakram & 20 & 100 & 0 & 0 \\
\hline
\end{tabular}

Berdasarkan tabel hasil belajar siklus II dapat dijelaskan sebagai berikut; 1) nilai rata-rata aspek afektif adalah 80,7 (kategori baik), 2) nilai rata-rata aspek kognitif adalah 83,7 (kategori baik), 3) nilai rata-rata aspek psikomotor adalah 82,7 (kategori baik), 4) Rata-rata nilai akhir (gabungan dari aspek afektif, kognitif, dan psikomotor) adalah 82,3 (kategori baik), 5) Ketuntasan belajar adalah 20 siswa (semua siswa dinyatakan tuntas) karena memenuhi KKM yaitu 75 .
Hasil kegiatan refleksi yang dijadikan bahan penyempurnaan layanan pembelajaran adalah efek hasil tindakan yang dilakukan yakni berupa perkembangan pembelajaran yang dapat dipaparkan sebagai berikut;

\section{Dampak Terhadap Motivasi Kepuasan Siswa dalam Proses Pembelajaran}

Motivasi memberikan pengaruh yang signifikan terhadap hasil belajar siswa.Pembelajaran 
lempar cakram dengan modifikasi cakram dari piring plastik mampu meningkatkan motivasi peserta didik terutama saat melaksanakan tugas gerak. Siswa merasa mendapatkan layanan baru dalam kegiatan belajar lempar cakram. Cakram yang terbuat dari piring plastik dengan spesifikasi bahan yang ringan lebih mampu membuka peluang untuk mengembangkan berbagai variasi latihan teknik dasar, sehingga memberikan tingkat kepuasan tersendiri bagi siswa dalam beraktivitas. Hal ini dibuktikan dengan aktivitas gerak siswa selama mengikuti kegiatan pembelajaran siswa lebih aktif melaksanakan tugas gerak yang diberikan oleh guru dibandingkan dengan cakram sesungguhnya. Dampak terhadap motivasi belajar disajikan pada histogram berikut:

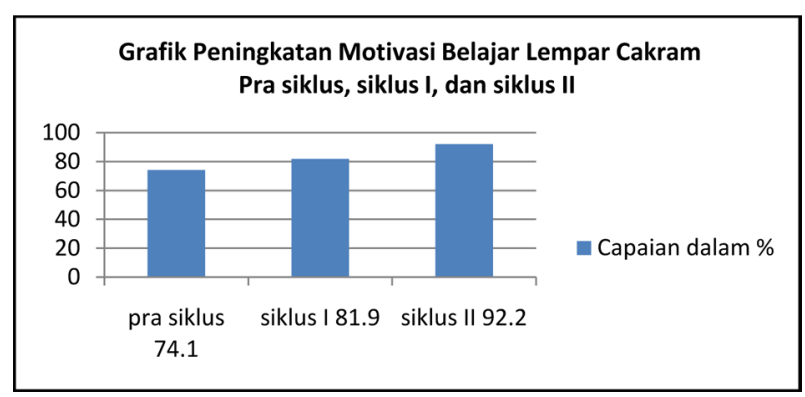

Grafik 1. Peningkatan Motivasi Belajar Lempar Cakram Pada Pra Siklus, Siklus I, dan Siklus II

Bukti bahwa penerapan modifikasi cakram dari piring plastik berdampak positif terhadap motivasi belajar siswa dapat dilihat pada hasil perhitungananalisis angket motivasi menunjukkan peningkatan yang signifikan yaitu; pada pra siklus $74,1 \%$, siklus I adalah $81,9 \%$, sedangkan pada siklus II adalah $92,2 \%$. Artinya dampak pembelajaran lempar cakram dengan modifikasi cakram dari piring plastikdapat meningkatkan motivasi belajar $7,8 \%$ pada siklus I dan $10,3 \%$ pada siklus II.

\section{Dampak Terhadap Capaian Peningkatan Hasil Belajar}

Suasana pembelajaran yang terbangun dengan baik melalui komunikasi antara guru dengan siswa akan memberikan dampak terhadap capaian hasil belajar. Penerapan modifikasi cakram dari piring plastik ternyata menjadi sarana terbangunnya komunikasi yang harmonis antara guru dengan siswakarena mampu memberikan layanan terbaik sesuai dengan karakteristik siswa. Dampak terhadap capaian nilai rata-rata hasil belajar lempar cakram disajikan pada histogram berikut:

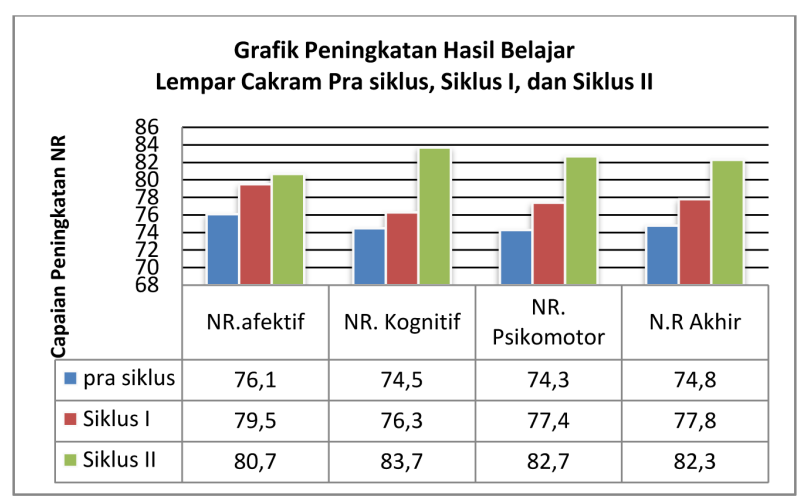

Gambar 2. Grafik Peningkatan Hasil Belajar Lempar Cakram Pra siklus, Siklus I, dan Siklus II

Grafik di atas memberikan gambaran bahwa pembelajaran lempar cakram dengan modifikasi cakram dari piring plastik dapat meningkatkan hasil belajar. Pada ranah afektif terjadi peningkatan 3,4 pada siklus I dan 1,2 pada siklus II, ranah kognitif terjadi peningkatan 1,8 pada siklus I dan 7,4 pada siklus II, ranah psikomotor terjadi peningkatan 3,1 pada siklus I dan 5,3 pada siklus II. Sedangkan nilai akhir (hasil belajar) terjadi peningkatan 3,0 pada siklus I (dari pra siklus 74,8 menjadi 77,8 pada siklus I) dan 4,5 pada siklus II (dari siklus I 77,8 menjadi 82,3 pada siklus II).

Hasil dari penelitian ini jika dibandingkan dengan hasil penelitian sebelumnya yaitu Penerapan Modifikasi Alat Pembelajaran Pendidikan Jasmani Untuk Peningkatan Hasil Belajar Atletik Nomor Lempar Cakram Pada Siswa Kelas VIII SMP Muhammadiyah 1 Pringsewu yang dilakukan oleh Angga Priakusuma, dkk. juga memberikan jawaban yang sama yaitu dapat meningkatkan hasil belajar siswa (ketuntasan belajar). Kondisi tersebut dapat disimpulkan bahwa penelitian tindakan kelas ini dapat dikatakan berhasil menjawab permasalahan yang ada. Kristiyanto (2010:65) menjelaskan bahwa berakhirnya siklus makro sebuah PTK ditentukan oleh pencapaian indikator makro. Tercapainya indikator makro juga didasarkan dari kesepakatan 
bulat antara peneliti utama dan kolaborator. Berdasar pendapat tersebut dengan indikator hasil penelitian yang telah dilaksanakan peneliti yang berkolaborasi dengan kolaborator maka penelitian tindakan kelas ini sudah dapat diakhiri (selesai) dan berhasil menjawab permasalahan.

\section{SIMPULAN}

Hasil dari analisis data pada penelitian tidakan kelas berupa penggunaan modifikasi cakram dari piring plastik terjadi peningkatan motivasi belajar siswa sebesar 7,8\% pada siklus I dan 10,3\% pada siklus II. Hasil belajar siswa juga terjadi peningkatan sebesar 3,0 pada siklus I dan 4,5 pada siklus II. Berdasarkan data analisis tersebut dapat disimpulkan; (1) modifikasi cakram dari piring plastik dapat meningkatkan motivasi belajar siswa dan (2) modifikasi cakram dari piring plastik dapat meningkatkan hasil belajar siswa.

Kesimpulan dari hasil penelitian ini memberikan makna yakni: (1) Guru harus merubah pembelajaran paradigma lama yang berpusat pada guru menjadi berpusat pada siswa. Perubahan ini mengharuskan setiap guru untuk melakukan kegiatan pembelajaran dengan menerapkan strategi yang sesuai dengan karakteristik siswa, (2) meskipun kegiatan pembelajaran PJOK banyak menghabiskan waktu untuk bergerak, namun tujuan pendidikan jasmani tidak sekedar membentuk siswa terampil dalam bidang psikomotor, tetapi lebih jauh dari itu tersentuhnya aspek afektif dan kognitif melalui kegiatan jasmani, (3) sebaiknya guru kreatif dan inovatif dalam menentukan strategi termasuk memanfaatkan potensi lingkungan sekitar guna meningkatkan layanan pembelajaran bagi siswa, (4) pemanfaatan benda yang berada di lingkungan belajar dalam hal ini dari piring plastik yang dimodifikasi menjadi cakram dapat dijadikan alternatif pilihan dalam upaya memudahkan siswa belajar lempar cakram. Guru dapat menerapkan penggunaan cakram modifikasi dari bahan plastik sebagai pengganti cakram yang sesungguhnya untuk kegiatan proses pembelajaran lempar cakram.

\section{DAFTAR PUSTAKA}

Arikunto, S., Suhardjono, \& Supriadi. (2012). Penelitian Tindakan Kelas. Jakarta: Bumi Aksara.

BSNP. (2006). Standar Isi. Jakarta: Badan Standar Nasional Pendidikan.

Depdiknas. (2000). Panduan Manajemen Sekolah. Jakarta: Direktorat Jenderal Pendidikan Dasar dan Menengah Direktorat Sekolah Lanjutan Tingkat Pertama.

Komarudin. (2013). Psikologi Olahraga Latihan

Keterampilan Mental dan Olahraga

Kompetitif. Bandung: PT Remaja

Rosdakarya.

Kemdikbud. (2013). Materi Pelatihan Guru Implementasi Kurikulu 2013 SMP

Penjasorkes. Jakarta: Badan Pengembangan Sumber daya Manusia Pendidikan dan Kebudayaan dan Penjaminan Mutu Pendidikan.

Kristiyanto, Agus. (2010). Penelitian Tindakan Kelas (PTK) dalam Pendidikan Jasmani \& Kepelatihan Olahraga. Surakarta: UNS Press.

Maisaroh dan Rostrinengsih. (2010). "Peningkatan Hasil Belajar Siswa dengan Menggunakan Metode Pembelajaran Active Learning Tipe Quiz Team Pada Mata Pelajaran Program Keterampilan Dasar Komunikasi di SMK Negeri 1 Bogor". Jurnal Ekonomi \& Pendidikan, 8 (12). 1-16.

Muhammad, Maryam. (2016). "Pengaruh Motivasi dalam Pembelajaran”. Lantanida Journal, 4 (2). 87-97.

Pratomo, Andre Tri. (2013). "Survei Sarana dan Prasarana Pembelajaran Pendidikan Jasmani Olahraga dan Kesehatan pada Sekolah Menengah Pertama Negeri sePurbalingga Tahun 2012". Journal of Physical Education, Sport, Health and Recreations, 2 (6). 372-375.

Slamento. (2010). Belajar dan Faktor-faktor yang Mempengaruhi. Jakarta: Rineka Cipta Sudijono,A.(2012).PengantarEvaluasi Pendidikan. Jakarta: PT. Raja Grafinda Persada. 
Suprijono, Agus. (2013). Cooperative Learning. Surabaya: Pustaka Belajar.

Susanto, E Budi. 2020. Penerapan Model-model Pembelajaran. Yogyakarta: Liberty.

Thohari. (2013). Menjadi Guru Kreatif \& Kompeten. Yogyakarta: Araska.

Undang-undang Republik Indonesia No. 14 Tahun 2005 tentang Guru dan Dosen. 